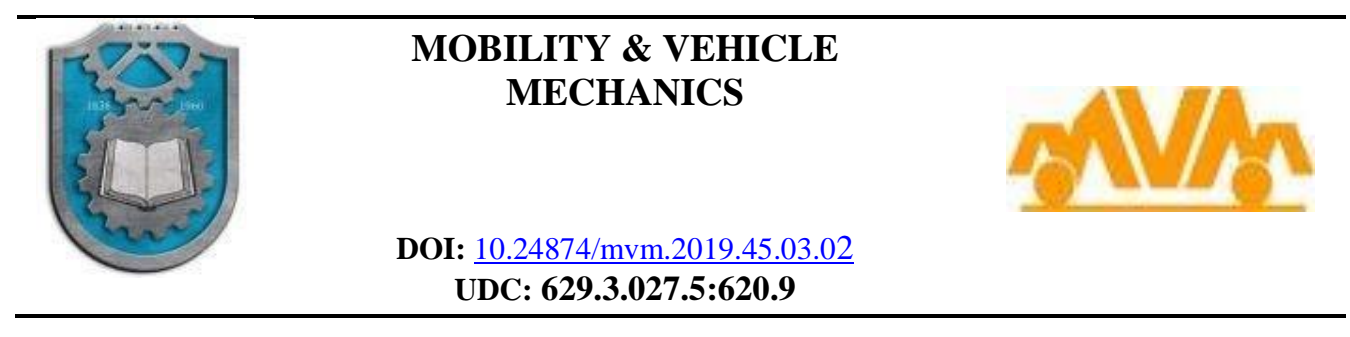

\title{
LIFE CYCLE ASSESSMENT OF THE CAR TIRE WITH ECO INDICATOR 99 METHODOLOGY
}

\author{
Angelina Pavlović ${ }^{1 *}$, Danijela Nikolić ${ }^{2}$, Saša Jovanović ${ }^{3}$, Goran Bošković ${ }^{4}$, Jasmina \\ Skerlic $^{5}$
}

Received in September 2019, Accepted in October 2019

RESEARCH ARTICLE

\begin{abstract}
Today automotive industry is a driving force for development of national economics so number of vehicle increases expeditiously. As an integral part of the vehicle, tires are generated annually in large amount all over the world. Growth of the car tires production affect environment and also the growth of non-degradable waste which has a large energetic potential but which currently is not fully used. The aim of this study is to evaluate the environmental impact of car tire during its whole life cycle and to identify activities in life-cycle phases that can be improved. That analysis can be achieved throughout its service life, from the acquisition of the raw materials through to the recycling of the worn tire, because the tire constantly interacts with the environment. Approaches to effectively reducing the negative environmental impact can be demonstrated only on the basis of detailed knowledge of this interaction.
\end{abstract}

(C) 2018 Published by University of Kragujevac, Faculty of Engineering

\footnotetext{
${ }^{1}$ Angelina Pavlović, University of Kragujevac, Faculty of Engineering, Sestre Janjić 6, 34000 Kragujevac, Serbia, djina1107@gmail.com (*Corresponding author)

${ }^{2}$ Danijela Nikolić, University of Kragujevac, Faculty of Engineering, Sestre Janjić 6, 34000 Kragujevac,Serbia, danijelan@kg.ac.rs

${ }^{3}$ Saša Jovanović, University of Kragujevac, Faculty of Engineering, Sestre Janjić 6, 34000 Kragujevac,Serbia, dviks@kg.ac.rs

${ }^{4}$ Goran Bošković, University of Kragujevac, Faculty of Engineering, Sestre Janjić 6, 34000 Kragujevac, Serbia, goran.boskovic@kg.ac.rs

${ }^{5}$ Jasmina Skerlić, University of Kragujevac, Faculty of Engineering, Sestre Janjić 6, 34000 Kragujevac, Serbia, jskerlic@kg.ac.rs
} 
This is why a life cycle assessment quantifies the material and energy flows in the different stages of a tire's life cycle (life cycle inventory analysis) and describes the interaction with the environment (impact assessment and interpretation). In this study, environmental impact is evaluated by using methodology Eco Indicator 99, which is one of the most widely used impact assessment methods in Life Cycle Analysis (LCA).

KEY WORDS: LCA, Eco-indicator 99, product, tire

\section{ANALIZA ŽIVOTNOG CIKLUSA AUTOMOBILSKE GUME POMOĆU METODOLOGIJE - EKO INDIKATOR 99}

REZIME: Danas se automobilska industrija smatra pokretačkom snagom razvoja nacionalnih ekonomija, pa se iz tog razloga broj proizvedenih vozila u svetu ekspeditivno povećava. Takođe, kao sastavni deo jednog automobila, broj proizvedenih autombilskih guma u svetu se povećava. Rast proizvodnje automobilskih guma ima negativan uticaj na životnu sredinu, što se može objasniti i povećanom količinom generisanog gumenog otpada. Cilj ove studije je proceniti uticaj automobilskih guma na životnu sredinu tokom čitavog životnog ciklusa, ali i identifikovati aktivnosti u životnom siklusu automobilske gume koje je moguće poboljšati, a u svrhu smanjenja negativnog pritiska na okolinu. Naime, automobilska guma nakon faze upotrebe ima veliki energetski potencijal, koji se trenutno ne koristi u potpunosti. Spomenuta analiza se sprovodi tokom celog životnog ciklusa gume, od procesa nabavke sirovina za proizvodnju, pa do procesa tretiranja/odlaganja istrošene gume. Mere efikasnog smanjenja negativnog uticaja na životnu sredinu, mogu se definisati samo na osnovu detaljne analize interakcije automobilske gume i okoline tokom njenog životnog veka. Zbog toga se procenom životnog ciklusa pneumatika kvantitativno određuju materijalni i energetski tokovi u različitim fazama životnog ciklusa (analiza inventara životnog ciklusa) i opisuje interakcija sa okolinom (procena uticaja i interpretacija). U ovom radu uticaj na životnu sredinu se procenjuje korišćenjem metodologije Eko Indikator 99, koja predstavlja jednu od najrazvijenijih metoda za ocenjivanje uticaja životnog ciklusa proizvoda na okolinu.

KLJUČNE REČI: analiza životnog ciklusa, Eko indikator 99, proizvod, guma 


\title{
LIFE CYCLE ASSESSMENT OF THE CAR TIRE WITH ECO INDICATOR 99 METHODOLOGY
}

\author{
Angelina Pavlović, Danijela Nikolić, Saša Jovanović, Goran Bošković, Jasmina Skerlić
}

\section{INTRODUCTION}

The automotive industry is one of the most developed industries in the world. That can be explained by the fact that the number of a vehicle increases expeditiously. In 2018, the international automotive industry produced an estimated 70.5 million passenger cars. Worldwide, passenger car sales are expected to continue to grow to about 80 million units in 2019 [1]. The vehicles were manufactured using a wide range of different types of materials in order to meet the highest needs of customers. End-of-life tires are one of the main sources of waste in end-of-life vehicles. At the end of the product lifecycle, complex multicomponent materials cannot be directly reused, such as the car tire. The number of vehicles on the market is growing as well as the number of tires that constantly interact with the environment. The car tire has a negative effect on the environment. Each year, more than half a million tons of worn tires are removed and replaced by a corresponding number of a new tires. In designing, construction and production of tires, care should be taken of energy efficiency and environmental protection so the aim of this study is to evaluate the impact of the car tire on the environment during its life cycle.

The concept of the product life cycle (PLC) was introduced in the fifties of the last century in the scientific researches. The existence of the biological life cycle is implemented on the products [2]. Namely, the PLC represents one cycle or the process from birth to death. The product life cycle is an important phenomenon because it describes all the phases through which it passes. In each phase, the product is interdependent with the society, economy and environment, and it encounters a number of limitations. From the view point of the environment, the current economic model is based on the transformation of resources into ready to use products and their disposal. This economic model, i.e. the product life cycle is not eco-friendly.

The previously mentioned fact can be proved by certain analyses, such as life-cycle assessment (LCA). The LCA is a technique to evaluate environmental impacts related to all the phases of a product's life cycle.

\section{LIFE-CYCLE ASSESSMENT METHOD}

As it is already mentioned, the LCA is a way for rating the environmental impacts of one product from raw material extraction through to its disposal. All stages in the life cycle of the product are considered in an LCA.

Namely, this assessment includes the entire life-cycle of a product and takes into account numerous activities: the extraction and processing of raw materials; manufacturing; transportation and distribution; use; reuse; maintenance; recycling; and final disposal [3]. LCA, as one environmental technique, has worldwide usage. The main reason for that can be explained by the fact that LCA represents an environmental tool that can help to identify opportunities for product improvement. Strengthened awareness that resources are limited as well as an increasing environmental pressure, were the motive for creating LCA concept. Usage of life-cycle assessment concept begun in the 1960s in different ways and under a variety of names [4]. Today there are many different definitions of LCA. 
The principles and framework of the LCA methodology are regulated in the International Standards Organization (ISO) documents 14040 and 14044. ISO 14040 and ISO 14044 define four phases of an LCA as shown in figure 1.

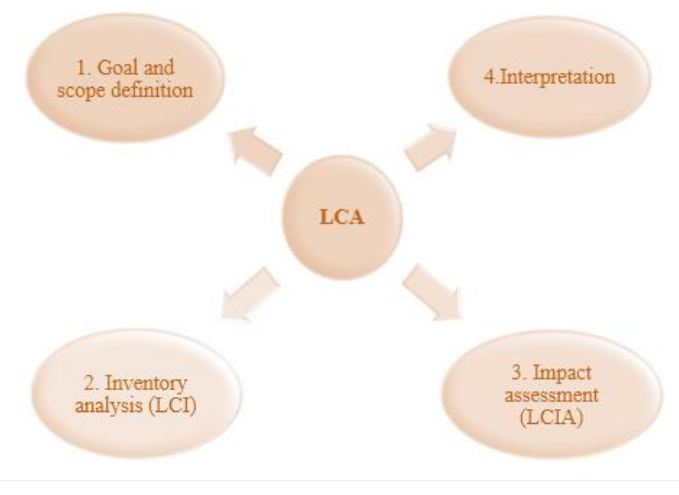

Figure 1. Phases of an LCA

According to ISO 14040, LCA is a technique for assessing the environmental aspects and potential impacts related with a product, by:

- compiling an inventory of relevant inputs and outputs of a product system

- evaluating the potential environmental impacts associated with those inputs and outputs by certain methodologies

- $\quad$ interpreting the results of the inventory analysis and impact assessment phases in relation to the objectives of the study [5].

Life-cycle assessment of products enable a reliably decision-making regarding a specific phase of the life cycle. With iterative approach such as LCA, it is possible to measure products environmental impacts, and thus select the strategies and measures for improving specific phases that are analyzed during the assessment of the product.

Due to its universality, LCA is used in almost all industry branches, in particular in machine building, construction, electronics, traditional and alternative energy, production of polymers, food products, product design and waste disposal.

\section{OBJECT OF ASSESSMENT}

Rubber is a natural or synthetic macromolecular substance which is converted by chemical reactions into a networked structure, which creates the new product - a tire or elastomer. The tire is an extremely tough material that can be reversibly elastic in a wide temperature range. Today, more than fifty thousand types of rubber products are produced, which can be grouped into several groups. One of those groups is pneumatics or tires.

The pneumatic is the only point of contact between the road and the vehicle. From the aspect of steering and maneuvering with the vehicle, the wheel and the tires are in the group of the most important vehicle assemblies, both for function and safety. Apart from transferring the entire mass of the vehicle to the ground, enabling the movement and maneuvering of vehicles, wheels with tires also attenuate the impact caused by uneven pavements, which are transmitted to all vehicle systems.

The characteristics of the tire, in addition to the construction, also depend on the materials used for their manufacture. Since the beginning of the automotive industry, the design of a 
car tire has changed over time. In fact, modern tires have over two hundred components. These components are divided into a few groups such as natural rubber, synthetic rubber, carbon and silicon, metallic and textile reinforcement cables, numerous chemical agents, etc [6]. Production of car tires requires a lot of raw materials, but bigger problem related to environmental arises when tires become waste. As a large number of worn tires are generated every year, it is very difficult to handle this much waste. Tires in the form of waste can be major environmental concern. The generation of waste tires can cause numerous problems such as fire hazards, environmental hazards and land usage [7].

Because of the above-mentioned problems, the life cycle assessment of a car tire has to be detailed done, from its cradle to its grave. The focus of this study is the environmental impact of the passenger car tire. The analyzed material composition of the tire corresponds to a summer tire that is produced by Continental [8]. In this research data for $175 / 70 \mathrm{R}-13$ tire is used.

\section{LIFE-CYCLE ASSESSMENT OF THE CAR TIRE}

In this research life-cycle assessment of the car tire is done by using the main methodological phases. Those phases are developed from the side ISO and they are already shown on figure 1 .

When the life-cycle analysis of the car tire is performing, all phases must be involved: from the stage of excavation, production and supply of raw materials for manufacturing of tires till stage of disposal of worn tires. Therefore, method of analyzing the life cycle of the car tire is divided into several phases:

- The production phase - includes the production of raw materials, their transport to production section, production of tires and packaging

- The distribution phase - involves the transport of the final product and the installation process on the car.

- The phase of use - includes using process scenarios and process such as maintenance or cleaning of the tires.

- The final phases - includes process of collecting the worn tires as well as different end-of-life scenarios (recycling, recover, reuse) of worn tires.

These phases are illustratively shown on figure 2 .

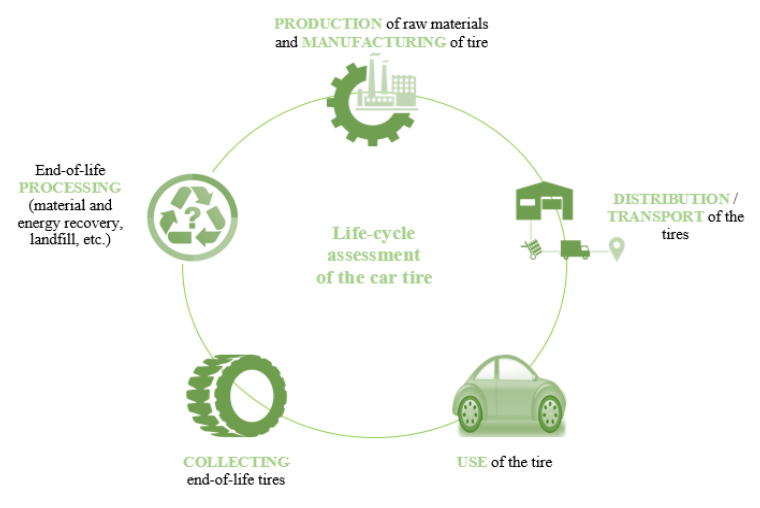

Figure 2. Life-cycle of the car tire

According to ISO documents life cycle assessment includes four steps that are analysed in next subsections for this case study. 


\subsection{Goal and scope of case study}

Goal definition and scope are crucial for all the other phases of LCA [9]. Definition of goal and scope of one case study includes the reason and the motive for performing a life-cycle analysis. Besides the reason and the motive of an LCA, this step must involve the description of the functional unit and the analyzed system boundaries.

The goal of an LCA study shall unambiguously state the intended application, the reasons for carrying out the study and the intended audience, i.e. to whom the results of the study are intended to be published [10].

The goal of this study is to analyze the environmental impacts of $175 / 70 \mathrm{R}-13$ car tire. This product is selected because the modern tire in operation (use phase) usually exceeds 60.000 to $130.000 \mathrm{~km}$. The duration of use mostly depends on the conditions of use. The problem occurs when for the safety reasons the tire must be replaced with a new one. According to the estimation, the natural process of decomposition of disposed tires lasts about 150 years [11]. The worn car tire has a negative impact on the environment so, in order to reduce that impact, it is necessary to do an LCA.

The goals of the conducted life-cycle assessment are the following:

- Analysis and explanation of the material and energy flows in the different phases in life-cycle of one tire

- Estimation of emissions and waste that go into the environment and that are considered like export flows.

- Recognition of the principal effect on the environment during the life-cycle of one tire.

- Identified opportunities to improve the environmental performance of the car tire during its life-cycle.

- Definition of measures for reducing the negative impact of worn tires on the environment.

- Evolution of one methodology for assessing tires, i.e. in general - rubber products.

During the life-cycle analyses of one product, the definition of the functional unit (FU) is required. The functional unit represents a measure of functional outputs and it complies with the requirements of the LCA study.

The basic purpose of the functional unit is to provide a reference level for normalization of input and output data, in order to further making comparisons based on LCA results [12].

In this research, it is assuming that the functional unit is one car tire with an average service life of $50.000 \mathrm{~km}$ over a four-year period. The weight of the analyzed tire is assumed approximately $6.5 \mathrm{~kg}$. The next important assignment in the phase of definition the goal and scope is to establish the system boundaries. The system boundaries determine which unit processes shall be included within the LCA [5]. The precise LCA considers the impact of all life-cycle of tires on the environment starting from obtaining the raw material till the end of the production process. Due to lack of available data, next processes are involved in the analysis: production of the tire, use the tire and transport of the tire.

\subsection{Life-cycle inventory analysis}

Life Cycle Inventory (LCI) analysis is the second phase of life-cycle assessment. This phase includes creating an inventory of flows from and to nature for a product system [13].

Namely, during this phase all the material flows, the energy flows as well as all the waste streams deliver to the environment over the whole life cycle of the analyzed product are identified and, when it is possible - are quantified. 
Based on the functional unit and initial resources quantification, as well as on the processes description presented above, it is feasible to create simple life-cycle "process tree", which will present the inventory analysis of the given product.

The process tree system includes only processes and transportation directly involved in the production, use and disposal of the analyzed product, the ancillary materials and the equipment [14]. The process tree of the car tire is shown on figure 3. The software STAN 2.6 was used to create model that represents process tree of the analysed car tire. Red arrows refer to flows that are considered as input flows. Blue arrows indicate the output flows which are almost always observed as harmful flows to the environment. The output flows of the life cycle inventory analysis are made up of the atmospheric emissions, emissions into water and waste stream.

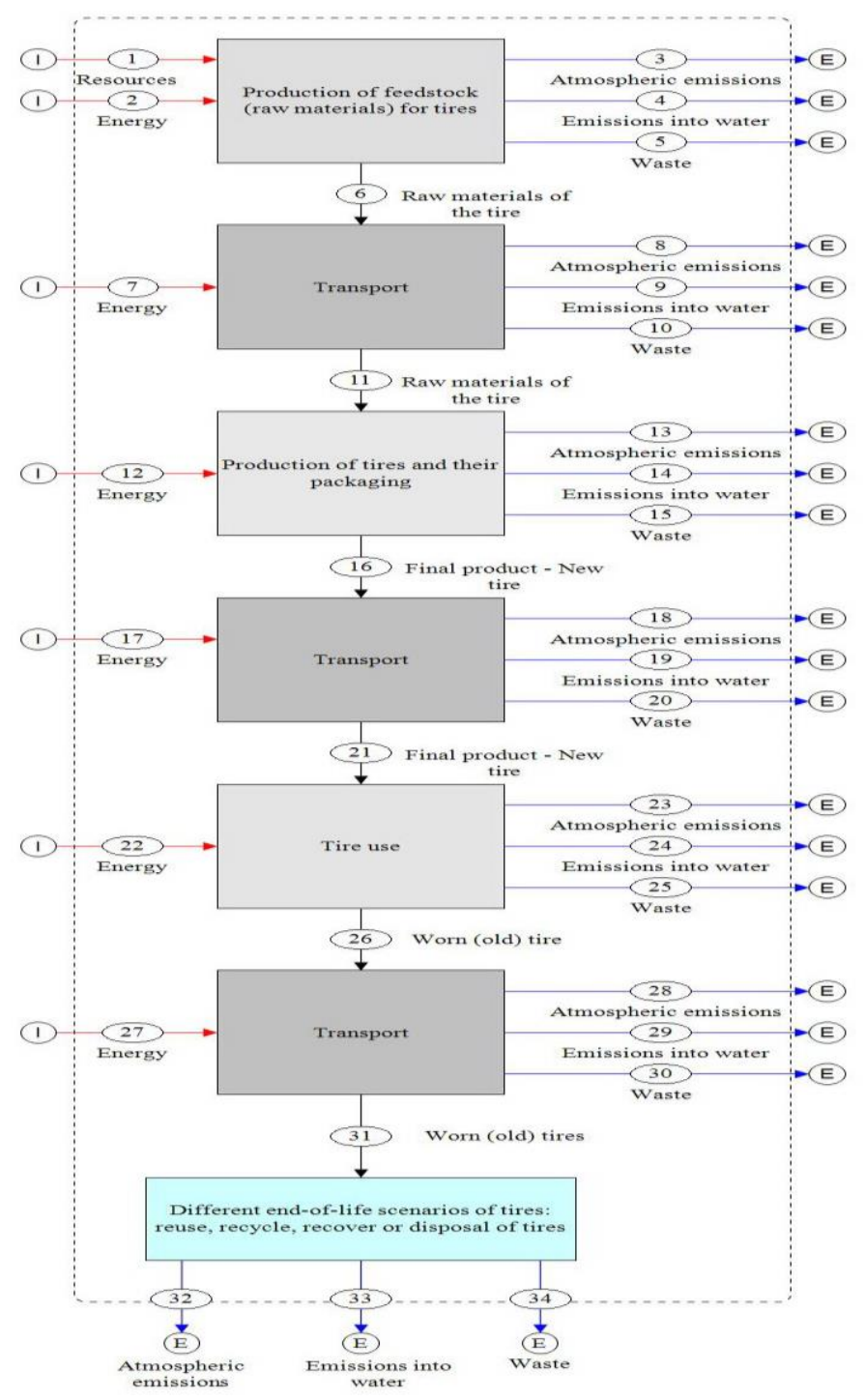

Figure 3. Process tree of the car tire (inventory analysis) 


\subsection{Life-cycle impact analysis}

Inventory analysis is followed by a life-cycle impact assessment (LCIA). This phase of LCA is aimed at evaluating the significance of potential environmental impacts based on the LCI flow results. The impact assessment framework is a multi-step process, starting by selecting and defining impact categories, which are relevant to the analyzed product. This is followed by a classification step, which assigns LCI results to the impact categories [3]. The objective of LCIA is to further process and interpret the results of LCI in terms of their potential impact on the environment and society [15]. Also, the LCIA gives all necessary data and information for the succeeding phase of LCA.

Life-cycle impact analysis is an important stage of LCA because according to results which are got from analysis, it can be defined strategy for reducing the impact of one product on the environmental.

The core principles of the LCIA phase are based on a methodology that is used for its performing. The essential step in this phase is a selection of methodology.

So far, a number of methodologies for assessing environmental impact have been developed and all of those are adapted to assessing impacts in different areas of LCA application.

In this case study, methodology Eco-Indicator 1999 (EI 99) is used because it is the only methodology that is possible to use with collected data.

\subsubsection{Methodology ECO-INDICATOR 99 and its implementation}

Eco-indicator 99 is one of the most widely used impact assessment methods in LCA. It is the successor of Eco-indicator 95 which allowed that an environmental load of a product is expressed in a single score $[16,17]$. The Eco-Indicator 99 methodology is one of the most developed methodologies for assessing the impact of the product life-cycle on the environment. The result of this method is called an eco-indicator that is expressed in points. The EI shows the overall estimated impact of a process or product on human health, the quality of ecosystems and the impoverishment of natural resources [18].

The standard Eco-indicator values can be regarded as dimensionless figures. All obtained values are expressed as the Eco-indicator point $(\mathrm{Pt})$. In this research work, milli-point $(\mathrm{mPt})$ is used as a unit of Eco-indicator. Following the Eco-Indicator 99 methodology, tables 1, 2 and 3 were filled up. These tables are related to impacts at each stage with their quantification in eco-points. The EI 99 includes weighting factors which represents a weight given to a data point (material or process)to assign it a lighter, or heavier, importance in one phase. According to the life-cycle inventory analysis and the assumed values of input flows, life-cycle impact analysis was done.

As already mentioned, more than two hundred raw materials are needed for the production of a single tire, therefore, in analyzing the environmental impact, only those that are most important was taken into the assessment. The amount of specific material or process is defined in accordance with the data from the company Continental [8].

The following tables show the final environmental impacts in specific phases of the car tire.

Table 1. Eco-indicator of production phase

\begin{tabular}{c|c|c|c}
\hline Material or process & Amount & Indicator & Result \\
\hline Rubber & $4.51 \mathrm{~kg}$ & 360 & $1,623.6$ \\
\hline Silica & $1.3 \mathrm{~kg}$ & 60 & 78 \\
\hline Carbon black & $2.8 \mathrm{~kg}$ & 180 & 504 \\
\hline
\end{tabular}




\begin{tabular}{c|c|c|c}
\hline Steel & $0.98 \mathrm{~kg}$ & 86 & 84.28 \\
\hline Coal & $1.4 \mathrm{~kg}$ & 4.2 & 5.88 \\
\hline Air & N/A & N/A & N/A \\
\hline Water & N/A & N/A & N/A \\
\hline Gas-fired heat (forming) & $13 \mathrm{MJ}$ & 5.3 & 68.9 \\
\hline Total [mPt] & $\mathbf{2 , 3 6 4 . 6 6}$ \\
\hline
\end{tabular}

Table 2. Eco-indicator of transportation phase

\begin{tabular}{c|c|c|c}
\hline Material or process & Amount & Indicator & Result \\
\hline Petroleum & 0.5 & 210 & 105 \\
\hline Total $[\mathrm{mPt}]$ & $\mathbf{1 0 5}$ \\
\hline
\end{tabular}

Table 3. Eco-indicator of use phase

\begin{tabular}{c|c|c|c}
\hline Material or process & Amount & Indicator & Result \\
\hline Petroleum & 0.97 & 210 & $\mathbf{2 0 3 . 7}$ \\
\hline Air & N/A & N/A & N/A \\
\hline Total [mPt] & & $\mathbf{2 0 4}$ & \\
\hline
\end{tabular}

Due to insufficient data, the eco-indicator was not calculated for the end-of-life phases but according to literature, it can be concluded that the car tire has a big negative impact on the environment in this phases.

\subsection{Life-cycle interpretation}

The interpretation is the final phase of an LCA where the results of the other phases are considered together and analyzed in the light of the uncertainties of the applied data and the assumptions that have been made and documented throughout the study [19].

The results that are got are fairly clear - it is obvious, that the production phase implies the biggest environmental impact.

It must keep in mind, that for completion of the work, some strong assumptions are made, such as the amounts of materials and also, excluded some highly influential materials that could add significantly to that phase of PLC. Likewise, the end-of-life phase of the car tire was not considered as well as the different end-of-life scenarios of tires, such as reuse, recycling or disposal of tires. Taking into consideration the determined goal of this research, its clarity and simplicity as well as the constraint of data, it can be said, that the performed analysis is reasonable. The conducted analysis is not entirely accurate, because most of the used data in assessment is assumed. The quantities and environmental impact of the individual components in the input-output flows vary. To allow for a comparison of the individual phases in the life of a tire, it is a good idea to define a common reference size for all stages.

Besides the analyzed phases, LCA must take into account: cumulative energy input, global warming effect, acidification and nitrification. 


\section{CONCLUSION AND FURTHER RESEARCH}

Summarizing this work, it can be said that the life-cycle assessment is a very useful and undoubtedly necessary environmental procedure, which earned its place among the popular modern environmental management and performance tools.

The purpose of the LCA of one car tire is getting the results of its environmental impact during all life-cycle. Using this analysis, it is possible to monitor all phases of the tire's life cycle and take appropriate steps in the design phase of the car tire in order to minimize those impacts. The assessment of the impact of the car tire on the environment is a very complex task because a lot of data is taken into account and many situations are assumed.

On the basis of the conducted analysis, the most critical phase is the phase of production during the entire life-cycle of the car tire. Life-cycle assessment of the car tire is very important because this product has a big number of different raw materials that after the use phase, it has a potential and it can become one valuable resource in some other process of production. Changes in the process of production as well as in the end-of-life scenarios are necessary, i.e. transit from a linear model of production to a circular economic model is necessary. Exactly in that way, it is possible to reduce the footprint of the production phase of the car tire on the environment. That can be explained by the fact that in the process of production will not be used new raw materials because the already worn materials will be reused or recovered. In further research, this assessment will improve significantly through the constant development and modernization as well as updating of the database.

\section{REFERENCES}

[1] STATISTA, Estimated worldwide automobile production 2018, https://www.statista.com/ (accessed on May 2019).

[1] Osland, G. E.: "Origins and development of the product life cycle concept", Butler University, Indianapolis, Indiana, US, Professional Work, 1991.

[2] Khasreen, M. M., Banfil, P. F. G., Menzies, G. F.: "Life-Cycle Assessment and the Environmental Impact of Buildings": A Review, Sustainability, Vol. 1, No. 3, 2009, pp 674-701, doi:10.3390/su1030674.

[3] Selmes, D. G.: “Towards Sustainability: Direction for Life Cycle Assessment”, Heriot Watt University: Edinburgh, UK, PhD thesis, 2005.

[4] ISO - International Standrad Organization Environmental management - Life cycle assessment - Principles and framework, First edition, Switzerland, 1997.

[5] Michelin, How is a tire made? https://www.michelinman.com/US/en/help/how-is-atire-made.html (accessed on May 2019).

[6] USMAN, R. R. M.: "Life Cycle Assessment of Waste Car Tyres at Scandinavian Enviro Systems", Chalmers University of technology, Göteborg, Sweden, Master of Science Thesis, 2012.

[7] Krömer, S., Kreipe, E., Reichenbach, D., Stark, R.: "Life cycle assessment of a car tire", Continental AG, Hannover, Germany, 1999.

[8] Zbicinski, I., Stavenuiter, J., Kozlowska, B., Van de Coevering, H.: "Product design and life-cycle assessment", The Baltic University Press, Sweden, 2006, ISBN: 91975526-2-3.

[9] Guinee, J.: "Handbook on Life Cycle Assessment: Operational Guide to the ISO Standards", Kluwer Academic Publisher, US, 2002, ISBN: 1-4020-0228-9. 
[10] Stanojević, D., Rajković, M., Tošković, D.: "Management od used tires, accomplishments in the world and situation in Serbia (In Serbian language)", Chemical Industry Vol. 65, No. 6, 2011, pp 727-738 doi: 10.2298/HEMIND110729061S.

[11] Nikolić, D., Jovanović, S., Skerlić, J., Velemir, M., Aleksić, N.: "Life Cycle Analysis in the Building Sector (In Serbian language)", Journal: Energy-Economy-Ecology, 2018, ISSN: 03540-8651.

[12] Cao, C.: "Sustainability and life assessment of high strength natural fibre composites in construction", In book: Fan M, Fu F Advanced High Strength Natural Fibre Composites in Construction, Elsevir, 2017, pp 529-543, ISBN: 978-0-08-100411-1.

[13] Tillman, A. M., Ekvall, T., Baumann, H., Rydbergt, T.: "Choice of system boundaries in life cycle assessment", Journal Cleaner Production Vol. 2, No. 1, 1994, pp 21-29.

[14] Fokaides, F. A., Christoforou, E.: "Life cycle sustainability assessment of biofuels", In book: Luque R, Sze Ki Lin C,Wilson K, Clark J Handbook of Biofuels Production,2016, pp 41-60, DOI: 10.1016/B978-0-08-100455-5.00003-5.

[15] Goedkoop, M., Effting, S., Collignon, M.: "The Eco-indicator 99:A damage oriented method forlife-cycle impact assessment - Manual for designers", Second edition, Netherlands, 2000.

[16] Pre-sustainability, Eco-indicator 99: Manual for designers 2000, https://www.presustainability.com/download/EI99 Manual.pdf (accessed on May 2019).

[17] Goletić, Š.: "Life-cycle assessment of the chair on environment through Eco-indicator 99 (In Serbian language)", 10th research-expert conference with internatiional participation QUALITY 2017, Neum, Bosnia and Herzegovina, 2017.

[18] Hauschild, M., Bonou, A,, Olsen, S.I.: 2017 "Life-cycle Interpretation", In book: Hauschild M, Rosenbaum R, Olsen S (eds) Life Cycle Assessment, Springer, Cham, 2017, pp 323-334. 